\title{
Analysis about the Effects of Ease of Use Site, Information Quality, Purchasing Trust, and Price Impression Towards Using of Online Shopping Blibli on Community in Semarang
}

\author{
Annisa Endigalani, Amelia Saraswati, Fauzan Kautsar, and Rista Nurdianasari \\ Department of Magister Management, Universitas Diponegoro, Semarang \\ e-mail: annisaendigalani9@gmail.com
}

\begin{abstract}
This research aims to analyze the influence of ease of use site, quality information, purchasing trust, and the impression of price against visitor's shopping intention on Blibi. The sampling method used on this research is probability sampling with random sampling technique. Samples were collected from 258 respondents who are community in Semarang who have visited the site Blibi. Analysis method used here is multiple regression analysis which includes validity test, reliability test, classic assumption test, multiple linear regression test, t-test, f-test, determination test. The result showed that the ease of use of the site, quality informartion, purchasing trust, and the impression of price has positive influence towards the shopping intention.
\end{abstract}

Keywords - ease of use site, information quality, purchasing trust, price impression, shopping intention.

\section{INTRODUCTION}

$\mathrm{T}$ RADE is defined as a subsystem that promotes existing technology in the future so as to provide convenience in buying and selling negotiations between consumers and companies with a variety of conveniences offered (Anas and Marios, 2015). The purchase negotiation process carried out at the outlet bravely provides a variety of services provided for site visitors to make the desired product selection. Companies engaged in online, change the concepts they have designed and process these concepts so as to provide efficient and practical purchasing options for consumers.

In Indonesia itself, there are currently various kinds of companies engaged in online so as to provide benefits and convenience for someone to make purchases in accordance with what consumers want. Companies engaged in the online field provide practical alternatives in a buying and selling process and make it easy for consumers to shop online.

Decision making in a purchase can be seen on a variety of factors that have been considered by potential buyers. There are several types of factors that are considered before deciding to make a purchase such as ease of use of the site, the quality of accurate information, consumer confidence in the purchase, and the impression of the price.

This study aims to analyze the influence of ease of use of the site, quality of information, purchase confidence, and price impressions on online shopping intentions at BLIBLI.co.id on community in Semarang.

\section{THEORETICAL THOUGHTS AND HYPOTHESIS FORMULATION}

A. The Relationship between the Ease of Use of the Site and the Intention to Shop Online Visitors

With all the availability of the site and the progress of user ability, motivating someone to choose one online site compared to another can be influenced by their impression of the ease of use of the site. If a user finds difficulties in using the site, cannot find what he is looking for in the online store, or is unclear about the site being offered (for sale), the user basically leaves the online site directly because of the constraints (Pearson et al., 2007).

In a study conducted by Igbaria, et al (1995) and research conducted by Davis, et al (1989) showed ease of use was found to have an indirect buying effect and the effect was far more indirect mediating [1], [2]. Other research conducted by Shah, et al (2012) shows that ease of use directly affects the impression of benefits and purchase intentions [3]. And the research conducted by Ather (2015) states if there is a positive relationship between the ease of use of the site with shopping intentions [4].

Based on the description above, one research hypothesis is proposed as follows:

$\mathrm{H} 1$ : Ease of site use (X1) has a positive effect on shopping intentions (Y) on online outlets

\section{B. The Relationship between Information Quality and Online Shopping Outlet Visitor's Intention}

An online site must also focus on the reliability of product information so that the intention to end up buying and making repurchases will increase. Information content on the site includes text, images, graphics, layout, sound, motion and to make the right content decisions is very important for the design of a related site made as effective as possible.

In research conducted by Milan, et al (2015) shows that there is a positive influence on the quality of information on products that affect one's purchase intention. Research conducted by Lijuan (2015) also showed a positive influence between the quality of information and online purchases [5]. Furthermore, research conducted by Liu and Qiu (2013) shows that product information that is considered negative by someone has a direct impact on shopping interest [6]. 
Table 1.

Variables and Indicators

\begin{tabular}{|c|c|c|}
\hline $\begin{array}{l}\text { Variable } \\
\end{array}$ & Definition & Indicators \\
\hline $\begin{array}{l}\text { Ease of use } \\
\text { site }\left(X_{1}\right)\end{array}$ & $\begin{array}{l}\text { The ease of use of the site is the level of confidence } \\
\text { of consumers who believe if making a purchase } \\
\text { online does not require a large enough effort to } \\
\text { make a purchase. }\end{array}$ & $\begin{array}{l}\text { 1. Ease of online sites to use. } \\
\text { 2. Ease of purchasing products. } \\
\text { 3. Ease of finding the desired product. }\end{array}$ \\
\hline $\begin{array}{l}\text { Information } \\
\text { Quality }\left(X_{2}\right)\end{array}$ & $\begin{array}{l}\text { The quality of information is something that leads } \\
\text { to online store content that contains the } \\
\text { completeness of information, the accuracy of } \\
\text { information, and includes various things from the } \\
\text { products offered by the seller. }\end{array}$ & $\begin{array}{l}\text { 1. Information regarding a complete product description. } \\
\text { 2. Information on how to order products clearly } \\
\text { 3. All information provided is useful. }\end{array}$ \\
\hline $\begin{array}{l}\text { Purchasing Trust } \\
\left(\mathrm{X}_{3}\right)\end{array}$ & $\begin{array}{l}\text { Purchasing trust is a level of consumer confidence } \\
\text { in another party that is built from the integrity of } \\
\text { that party.. }\end{array}$ & $\begin{array}{l}\text { 1. Online shop can be trusted. } \\
\text { 2. Confidence that the seller can meet his obligations. } \\
\text { 3. Confidence that the seller will not commit fraud. }\end{array}$ \\
\hline $\begin{array}{l}\text { Price Impression } \\
\left(\mathrm{X}_{4}\right)\end{array}$ & $\begin{array}{l}\text { The price impression is the consumer's perception } \\
\text { of the price charged to an item based on the benefits } \\
\text { obtained. }\end{array}$ & $\begin{array}{l}\text { 1. The price offered is in accordance with the quality of the product } \\
\text { 2. Product prices tend to be cheaper compared to physical stores } \\
\text { 3. The price offered is in accordance with the benefits to be obtained }\end{array}$ \\
\hline $\begin{array}{l}\text { Shopping Intention } \\
\left(\mathrm{Y}_{1}\right)\end{array}$ & $\begin{array}{l}\text { Shopping intentions are the desires or inclinations } \\
\text { of a person to take action on a brand or take steps } \\
\text { related to a purchase. }\end{array}$ & $\begin{array}{l}\text { 1. Consumer interest to make a purchase } \\
\text { 2. Make the first choice. } \\
\text { 3. Interest to recommend to others. }\end{array}$ \\
\hline
\end{tabular}

Table 2.

Description of Respondents

\begin{tabular}{ccc}
\hline \hline Profile & Amount & Percentage \\
\hline Age & 142 & $55 \%$ \\
17-21 years old & 116 & $45 \%$ \\
22-26 years old & & $29 \%$ \\
Expenditures in 1 month & 76 & $55 \%$ \\
<Rp 1.000.000 & 141 & $11 \%$ \\
Rp 1.000.000 - Rp 2.000.000 & 28 & $4 \%$ \\
Rp 2.000.000 - Rp 3.000.000 & 11 & $1 \%$ \\
Rp 3.000.000 - Rp 4.000.000 & 2 & \\
>Rp 4.000.000 & & \\
\hline \hline
\end{tabular}

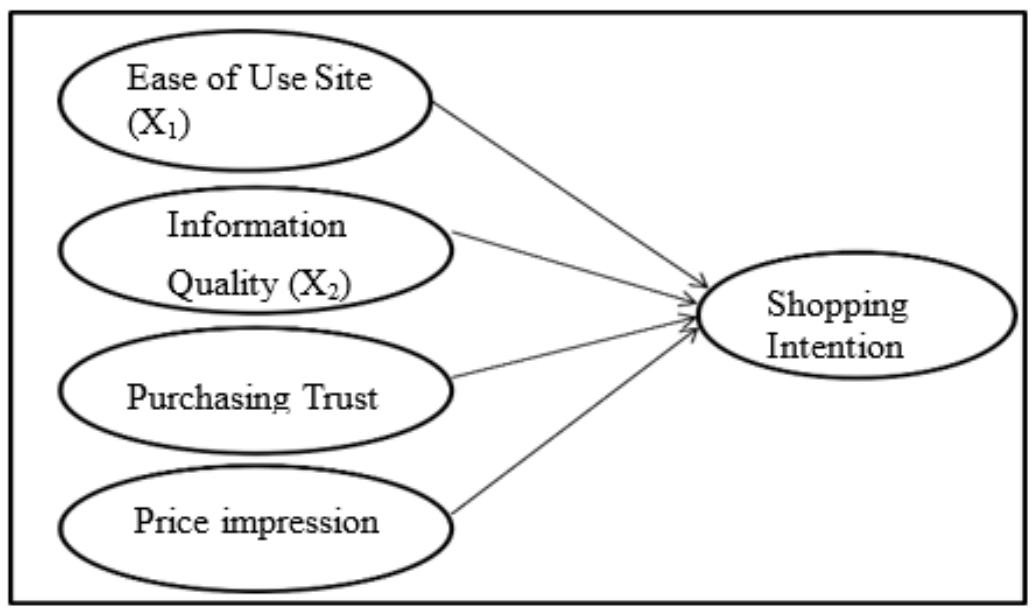

Figure 1. Theoretical Framework.

Based on the description above, one research hypothesis is proposed as follows:

H2: Information quality (X2) has a positive effect on shopping intentions $(\mathrm{Y})$ on online outlets

\section{Relationship between Purchasing Trusts and Online Shopping Visitors' Shopping Intent}

Prioritizing a trust is the main key in the success of a business venture. Institutional trust is directly related to users in general. Trust disposition is related to individual openness, awareness, and extroversion. Interpersonal trust is related to trust between the two parties who do business.

Research conducted by Pavlou (2003) states that buying intentions with consumers have a positive relationship with trust in purchases at online stores. Subsequent research conducted by Quack (2010) also proved that consumer confidence has a positive effect on purchase intentions. While research conducted by Ganguly, et al (2010) states that there is a negative collectivity between a belief in purchase intention [7].

Based on the description above, one research hypothesis is proposed as follows:

H3: Purchasing confidence (X3) has a positive effect on shopping intentions (Y) on online outlets.

\section{The Relationship between Price Impression and Online} Store Visitor Intention

Price is one of the variables considered in a purchase. The impression of a price that is interconnected with the purchase 
Table 3.

Validity and Reliability

\begin{tabular}{|c|c|c|c|c|}
\hline & "Standar Alpha & $\begin{array}{l}\text { Cronbach's } \\
\text { Alpha }\end{array}$ & r hitung & "Kesimpulan \\
\hline Ease of use site $\left(\mathrm{X}_{1}\right)$ & 0,700 & 0,882 & & Reliabel \\
\hline $\mathrm{X}_{1.1}$ Ease of use the online site & & & 0.926 & Valid \\
\hline $\mathrm{X}_{1.2}$ Ease of purchasing products & & & 0,905 & Valid \\
\hline $\begin{array}{l}\mathrm{X}_{1.3} \text { Ease of finding the desired product } \\
\text { Information Quality }\left(\mathrm{X}_{2}\right)\end{array}$ & 0,700 & 0,821 & 0,868 & $\begin{array}{l}\text { Valid } \\
\text { Reliabel }\end{array}$ \\
\hline $\mathrm{X}_{2.1}$ Complete product information & & & 0,884 & Valid \\
\hline $\mathrm{X}_{2.2}$ Product order information is clear & & & 0,888 & Valid \\
\hline $\begin{array}{l}\mathrm{X}_{2.3} \text { Product related information provides benefits before making a } \\
\text { purchase }\end{array}$ & & & 0,800 & Valid \\
\hline Purchasing Trust $\left(\mathrm{X}_{3}\right)$ & 0,700 & 0,896 & & Reliabel \\
\hline $\mathrm{X}_{3.1}$ Trusted online site & & & 0,882 & Valid \\
\hline $\mathrm{X}_{3.2}$ The seller sends out the items ordered & & & 0,916 & Valid \\
\hline $\mathrm{X}_{3.3}$ The seller does not commit fraud & & & 0,931 & Valid \\
\hline Price Impression $\left(\mathrm{X}_{4}\right)$ & 0,700 & 0,861 & & Reliabel \\
\hline $\mathrm{X}_{4.1}$ The price offered is in accordance with the quality of product & & & 0,874 & Valid \\
\hline $\mathrm{X}_{4.2}$ Products are cheaper compared to physical store & & & 0,889 & Valid \\
\hline $\mathrm{X}_{4.3}$ Prices are correspond with product benefits & & & 0,895 & Valid \\
\hline Shopping intention(Y) & 0,700 & 0,874 & & Reliabel \\
\hline Y1 Intention to make purchases at online outlets & & & 0,860 & Valid \\
\hline Y2 Make online outlets the first choice to shop & & & 0,912 & Valid \\
\hline Y3 Recommends online outlets to others & & & 0,911 & Valid \\
\hline
\end{tabular}

Table 4.

Results of Multiple Regression Analysis Coefficients ${ }^{\mathrm{a}}$

\begin{tabular}{|c|c|c|c|c|c|c|}
\hline \multirow{2}{*}{\multicolumn{2}{|c|}{ Model }} & \multicolumn{2}{|c|}{ Unstandardized Coefficients } & \multirow{2}{*}{$\begin{array}{c}\text { Standardized Coefficients } \\
\text { Beta } \\
\end{array}$} & \multirow{2}{*}{$\mathrm{t}$} & \multirow{2}{*}{ Sig. } \\
\hline & & B & Std. Error & & & \\
\hline & (Constant) & ,004 & 1,084 & & ,004 & 997 \\
\hline & Ease to Use Site & 167 & ,069 & 153 & 2,406 & 017 \\
\hline & Information Quality & ,166 & 081 & 142 & 2,065 & 040 \\
\hline & Purchasing Trust & 155 & ,062 & ,164 & 2,495 & 013 \\
\hline & Price Impression & ,469 & ,063 & ,432 & 7,436 &, 000 \\
\hline
\end{tabular}

desire influences the purchase [8]. So if the price sold has a high value and not a few then not a few of consumers feel financial losses. Especially if the price paid is not in accordance with the expected product.

In a previous study put forward by Simon (2011) states that the impression of price has a positive effect on purchasing intentions of a person [9]. Research conducted by Babin, et al (2003) shows that there is a positive relationship between perceived fairness of price and purchase interest [10]. According to research conducted by Dodds, et al (1991) states that the perceived price is seen to have a negative impact on one's purchase intention [11].

Based on the description above, one research hypothesis is proposed as follows:

H4: Price impression (X4) has a positive effect on shopping intentions $(\mathrm{Y})$ on online stores.

\section{RESEARCH METHODS}

\section{A. Research variable}

In this study the variables used consisted of the dependent variable, the independent variables and variables used were ease of use site, information quality, purchasing trust, and price impression [2], [12]-[21].

\section{B. Population and Sample}

Sugiyono (2008) defines the population as an area of certain objects and subjects that have the quality and character that are decided by researchers to be studied and then drawn conclusions [22]. The population consists of a combination of all data elements in the form of events, things, or individuals who have similar characteristics that are the center of the universe in research [23]. In this study, the population was community in Semarang who had visited BLIBLI.co.id.

Ferdinand (2006) states that sample is a subset or part of the population that is composed by a part of the population. This study uses a sampling method that is probability sampling with random sampling techniques. The sample used in this study was 258 respondents who were communities in Semarang.

\section{Data Analysis Method}

In this study, the method of data collection is done by distributing questionnaires or questionnaires. The data analysis method used is the multiple regression analysis method with the Statistical Package for Social Science program SPSS version 22

\section{Research Results And Discussion}

Respondents in this study were community in Semarang with the provisions having visited online sites BLIBLI.co.id. In this study, the process of distributing questionnaires was addressed to 258 respondents.

A total of 258 questionnaires were distributed and filled out by respondents. The categories of respondents are divided 
Table 5.

F Test ANOVA

\begin{tabular}{llrrrrr}
\hline \hline & Model & Sum of Squares & Df & Mean Square & F & Sig. \\
\hline 1 & Regression & 3065,078 & 4 & 766,269 & $\mathbf{1 0 2 , 2 7 6}$ &, $000^{\mathrm{b}}$ \\
& Residual & 1895,527 & 253 & 7,492 & & \\
& Total & 4960,605 & 257 & & & \\
\hline \hline
\end{tabular}

Table 6.

Determination Coefficient Test $\left(\mathrm{R}^{2}\right)$

\begin{tabular}{|c|c|c|c|c|c|c|c|c|c|}
\hline \multirow[t]{2}{*}{ Model } & \multirow[t]{2}{*}{$\mathbf{R}$} & \multirow[t]{2}{*}{ R Square } & \multirow{2}{*}{$\begin{array}{l}\text { Adjusted R } \\
\text { Square }\end{array}$} & \multirow{2}{*}{$\begin{array}{l}\text { Std. Error of the } \\
\text { Estimate }\end{array}$} & \multicolumn{5}{|c|}{ Change Statistics } \\
\hline & & & & & $\begin{array}{c}\text { R Square } \\
\text { Change }\end{array}$ & F Change & df1 & df2 & Sig. F Change \\
\hline 1 & $.786^{\mathrm{a}}$ & .618 & .612 & 2.7372 & .618 & 97.498 & 4 & 253 & .000 \\
\hline
\end{tabular}

into several categories, including gender, age, expenses in one month, as well as information they know about BLIBLI. 1) Multiple Regression Analysis

This study uses multiple regression analysis techniques with SPSS version 22. The purpose of multiple lianear regression is to determine the relationship between a dependent variable with more than one independent variable displayed in the form of a regression equation.

\section{The analysis results for Table 4 are as follows:}

a) Dependent Variable: Shopping Intention.

Based on these results, the regression equation obtained is as follows:

$\mathrm{Y} 1=0.153 \mathrm{X} 1+0.142 \mathrm{X} 2+0.164 \mathrm{X} 3+0.432 \mathrm{X} 4$

From the results of the analysis it can be seen that all major independent variables (ease of use of the site, quality of information, purchase confidence, and price impressions) have a positive and significant effect on shopping intentions ( $\operatorname{sig}<0.05$ ). Based on the equation it is known that the most influential independent variable is the price impression with a coefficient of 0.432 . Then followed by the purchase confidence variable with a coefficient of 0.164 then ease of use of the site with a coefficient of 0.142 and the quality of information with a coefficient of 0.142 .

The analysis results for Table 5 are as follows:

a) Dependent Variable: Shopping Intention

b) Predictors: (Constant), Price Impression, Ease to Use Site, Purchasing Trust, Information Quality.

The analysis results for Table 6 are as follows:

Based on the above table it can be concluded if the equation model of this study has an F count of 102.276 with a significance level of 0.000 which is smaller 0.05 . So it can be concluded if the independent variables in this study have a joint influence on the dependent variable.

a) Predictors: (Constant), Price Impression, Ease of Use Site, Purchasing Trust, Information Quality

b) Dependent VariableIn addition, it is also known that the adjusted $\mathrm{R}$ square value is 0.612 . This shows that the independent variables in this study, namely the ease of use of the site, the quality of information, purchase confidence, and the impression of price are able to explain variations that occur in the variable spending intentions of $61.2 \%$. While the remaining $38.8 \%$ is explained by other factors outside the model.

\section{CONCLUSION}

The conclusion of this study is that there can be a positive and significant influence between the independent variables, namely the ease of use of the site, the quality of information, purchase confidence, and price impressions with the dependent variable, namely shopping intentions at BLIBLI Indonesia.

The easier it is for a site to be used, the higher the shopping intention for a person. This will be different if the site is difficult to use and understand, then one's shopping intentions will decrease due to limitations in using the online site. The greater the quality of existing product information relating to information and descriptions of the products offered, it will increase shopping intentions on oneself. This will be different if the quality of information of an incomplete product explains the product description in detail, so it can reduce shopping intentions. The greater the trust formed in a person eats the greater the intention to make a purchase. This will be different if there is a sense of distrust in someone due to fraud, a product that is not in accordance with the expectations and a lack of trust in the seller, then it can reduce shopping intentions. The greater the price impression in accordance with the product in accordance with what is desired by consumers, the greater the intention to shop. This will be different if the impression of the price formed is not good because the impression of the price of the product is too expensive, the impression of the price regarding the price comparison with a physical store that is thought to be more expensive, and the impression of a price that is felt to be incompatible with its benefits, this will reduce one's shopping intention.

\section{MANAGERIAL IMPLICATIONS}

In this study, researchers conducted a re-explanation related to the influence between variables that had been done before. Sourced from research hypotheses and theoretical frameworks, this research will have implications for previous studies to strengthen the results of this study.

First, the ease of use of the site has a positive effect on shopping intentions. This is reinforced by the results of previous studies by Shah, et al (2012) which show that the ease of use of a site directly affects the impression of benefits on purchases. 
February $1^{\text {st }}$ 2020, Institut Teknologi Sepuluh Nopember, Surabaya, Indonesia

And the research conducted by Ather (2015) states if there is a positive relationship between the ease of use of the site with shopping intentions.

So it can be concluded that if the level of ease of use of the site, the higher the consumer's shopping intentions.

Second, the quality of information has a positive influence on shopping intentions. This is reinforced by the results of previous studies by Milan, et al (2015) showing that there is a positive influence on the quality of information on products that affect one's purchase intention. Furthermore, the research conducted by Lijuan (2015) also showed a positive influence between the quality of information and online purchasing. So it can be concluded if the higher the quality of information contained in product sales, the higher the intention of consumer spending.

Third, consumer confidence has a positive influence on shopping intentions. This is reinforced by the results of previous studies by Pavlou (2003), mentioning that buying intentions to consumers have a positive relationship to trust in purchases at online stores. Subsequent research conducted by Quack (2010) also proved that consumer confidence has a positive effect on purchase intentions. So it can be concluded if the higher the confidence in consumers, the higher the intention to shop.

Fourth, the impression of price has a positive influence on shopping intentions. This is reinforced by the results of previous research by Simon (2011) stating that the impression of price has a positive impact on purchasing intentions in a person. Furthermore, research conducted by Babin, et al (2003) shows that there is a positive relationship between perceived fairness of price and purchase interest. So it can be concluded if the higher the price impression in accordance with the products offered by the seller, the higher the intention to shop.

\section{LIMITATIONS OF RESEARCH AND FUTURE RESEARCH SUGGESTIONS}

In the research that has been done, of course there are still some limitations and deficiencies in the preparation of this study. It is expected that future studies will be able to perfect this research.

Limitations in this study are the first, researchers only distributed questionnaires to be filled out by respondents totaling 258. The number is still considered to be insignificant compared to BLIBLI online site visitors in Indonesia.

Second, written questionnaire distribution techniques have not been able to describe the answers of respondents. There are several suggestions for BLIBLI on the questionnaire that were not filled out by respondents. To improve the quality of respondents' answers, it is better to do interview techniques so that they can find out exactly what the respondents want and feel about the BLIBLI Indonesia online site.

Suggestions for this research are expected for further research, researchers are expected to add a larger and more comprehensive sample so that it can meet the overall characteristics of BLIBLI online site users. In addition, researchers are expected to not only use a written questionnaire to find out the respondent's answer, but also conduct interview techniques directly to the respondent so that they know the answer more specifically.

\section{REFERENCE}

[1] M. Igbaria and J. Iivari, "The effects of self-efficacy on computer usage,” Omega, vol. 23, no. 6, pp. 587-605, 1995.

[2] F. D. Davis, "Perceived Usefulness, Perceived Ease of Use, and User Acceptance of Information Technology,” MIS Q. Manag. Inf. Syst., vol. 13, no. 3, pp. 319-339, 1989, doi: 10.2307/249008.

[3] S. S. H. Shah et al., "The impact of brands on consumer purchase intentions,” Asian J. Bus. Manag., vol. 4, no. 2, pp. 105-110, 2012.

[4] A. Akhlaq and E. Ahmed, "Digital commerce in emerging economies," Int. J. Emerg. Mark., 2015.

[5] G. Sharma and W. Lijuan, "The effects of online service quality of ecommerce Websites on user satisfaction,” Electron. Libr., 2015.

[6] X. Liu and J. Qiu, "The impact of the negative online reviews on consumers' purchase intention: Based on the dimension of product information.," in WHICEB, 2013, p. 22.

[7] B. Ganguly, S. B. Dash, D. Cyr, and M. Head, "The Effects of Website Design on Purchase Intention in Online Shopping: the Mediating Role of Trust and the Moderating Role of Culture," Int. J. Electron. Bus., vol. 8, no. 4/5, p. 302, 2010, doi: 10.1504/ijeb.2010.035289.

[8] F. Guzmán, O. Iglesias, A. Cuneo, P. Lopez, and M. J. Yague, "Private label brands: measuring equity across consumer segments,” J. Prod. Brand Manag., 2012.

[9] S. Lee, A. Illia, and A. Lawson-Body, "Perceived price fairness of dynamic pricing,” Ind. Manag. Data Syst., 2011.

[10] B. J. Babin, D. M. Hardesty, and T. A. Suter, "Color and shopping intentions: The intervening effect of price fairness and perceived affect,” J. Bus. Res., vol. 56, no. 7, pp. 541-551, 2003.

[11] W. B. Dodds, K. B. Monroe, and D. Grewal, "Effects of price, brand, and store information on buyers' product evaluations," J. Mark. Res., vol. 28, no. 3, pp. 307-319, 1991.

[12] J.-H. Wu and S.-C. Wang, "What Drives Mobile Commerce?: An Empirical Evaluation of The Revised Technology Acceptance Model,” Inf. Manag., vol. 42, no. 5, pp. 719-729, 2005.

[13] T. C. Kinnear and J. R. Taylor, Marketing research: an applied approach. McGraw-Hill Companies, 1987.

[14] B. H. Wixom and P. A. Todd, "A theoretical integration of user satisfaction and technology acceptance,” Inf. Syst. Res., vol. 16, no. 1, pp. 85-102, 2005.

[15] G. S. Milan, S. Bebber, D. De Toni, and L. Eberle, "Information quality, distrust and perceived risk as antecedents of purchase intention in the online purchase context," J. Manag. Inf. Syst. E-commerce, vol. 2, no. 2, pp. 111-129, 2015.

[16] P. A. Pavlou and M. Fygenson, "Understanding and predicting electronic commerce adoption: An extension of the theory of planned behavior,” MIS Q. Manag. Inf. Syst., vol. 30, no. 1, pp. 115-143, 2006, doi: $10.2307 / 25148720$.

[17] P. A. Pavlou, "Consumer acceptance of electronic commerce: Integrating trust and risk with the technology acceptance model,” Int. J. Electron. Commer., vol. 7, no. 3, pp. 101-134, 2003.

[18] C.-M. Chiu, C.-C. Chang, H.-L. Cheng, and Y.-H. Fang, "Determinants of customer repurchase intention in online shopping," Online Inf. Rev., 2009.

[19] G. M. Armstrong, P. Kotler, M. Harker, and R. Brennan, Marketing: an introduction. Pearson UK, 2018.

[20] A. Mehta, "How advertising response modeling (ARM) can increase ad effectiveness,” J. Advert. Res., vol. 34, p. 62, 1994.

[21] F. Tjiptono, Strategi Pemasaran. Yogyakarta: Andi Offset, 2007.

[22] P. D. Sugiyono, Metode Penelitian Kunatitatif Kualitatif dan R\&D. Bandung: Alfabeta, 2008.

[23] A. Ferdinand, "Metode Penlitian Manajemen Pedoman Penelitian Untuk Menulis Skripsi Tesis dan Disertai Ilmu Manajemen, Edisi Ke Tiga.” Semarang, Universitas Dipenogoro, 2011. 